p-ISSN 2407-4462

e-ISSN 2614-5812
Jurnal TARBA WY

Jurnal Pendidikan Islam

Volume 4 Nomor 2, Desember 2017, Hlm 230-241

Akses Online :

http:// jurnal.lp2msasbabel.ac.id

Dipublikasikan oleh :

Fakultas Tarbiyah IAIN Syaikh Abdurrahman Siddik Bangka Belitung

Info Artikel:

\title{
PEMANFAATAN ICT (INFORMATIONS AND COMMUNICATION TECHNOLOGIES) DALAM PEMBELAJARAN ANAK USIA DINI
}

\author{
Abdi Susanto, M.Pd \\ IAIN Syaikh Abdurrahman Siddik Bangka Belitung \\ abdysusanto84@yahoo.com
}

\begin{abstract}
The presence of Information Communication and Technology (ICT) in Information and Communication Technology (ICT) has penetrated every area of human life, including in the world of education. The role of ICT in the world of education is very large, not only among higher education institutions but also in early childhood education. In Amendment to the 1945 Constitution article 28 paragraph 2, it is stated that every child has the right to develop themselves through meeting their basic needs, having the right to education and to benefit from science and technology, art and culture, to improve their quality of life and for the welfare of mankind In order to develop early childhood, many of us now find a variety of formal and nonformal education services. Whatever the form of service, it should pay attention to the principles of early childhood learning. In addition to paying attention to the principle of learning, the scope of material provided is also very diverse according to aspects of child development. Various media can be used from those found in the child's own body such as fingers and toes, clothing, colorful eating utensils and various sizes, beams, plants, even sophisticated multi-media (technology) must be designed according to age and needs. early childhood development. This is because in order to optimize all the potential that exists in the child. So that in turn a solid foundation will be formed in the future.
\end{abstract}

\begin{abstract}
Abstrak
Penelitian ini merupakan penelitian tindakan yang menggunakan metode deskriptif. Teknik pengumpulan data menggunakan studi observasi, dokumentasi, dan wawancara. Sedangkan analisis data dilakukan dengan cara menelaah seluruh data yang tersedia dari berbagai sumber, mereduksi data di mana reduksi data dilakukan dengan jalan membuat abstraksi, menyusun data
\end{abstract}


dalam satuan-satuan yaitu data yang telah tersusun dalam satuan-satuan dikategorisasikan, kategori dilakukan sambil membuat koding, mengadakan pemeriksaan keabsahan data, penafsiran data, dan kesimpulan. Hasil penelitian menunjukkan bahwa pelaksanaan pembelajaran bahasa Indonesia dengan model kuantum dapat dikatakan telah berhasil. Hal ini terlihat dari hasil tes (evaluasi) yang dilakukan oleh guru terhadap siswa, di mana dari tahapan-tahapan pembelajaran yang dilakukan (mulai dari prasiklus sampai dengan siklus I dan II) selalu mengalami peningkatan nilai yang baik secara terus-menerus. Kehadiran Information Communication and Technologi (ICT) Teknologi Informasi dan Komunikasi (TIK) telah merambah dalam setiap bidang kehidupan manusia, termasuk dalam dunia pendidikan. Peranan ICT dalam dunia pendidikan sangatlah besar, tidak hanya dikalangan perguruan tinggi semata namun juga pada pendidikan anak usia dini. Dalam Amandemen Undang-Undang Dasar 1945 pasal 28 ayat 2, dinyatakan bahwa setiap anak berhak mengembangkan diri melalui pemenuhan kebutuhan dasarnya, berhak mendapatkan pendidikan dan memperoleh manfaat dari ilmu pengetahuan dan teknologi, seni dan budaya, demi meningkatkan kualitas hidupnya dan demi kesejahteraan umat manusia dalam rangka mengembangkan diri anak usia dini, sekarang banyak kita dapati berbagai layanan pendidikan baik formal maupun non-formal. Apapun bentuk layanan tersebut, seyogyanya memperhatikan prinsipprinsip pembelajaran anak usia dini. Selain memperhatikan prinsip pembelajaran, cakupan materi yang diberikan juga sangat beragam sesuai dengan aspek perkembangan anak. Berbagai media dapat digunakan dari yang terdapat pada tubuh anak sendiri seperti jari tangan dan kaki, pakaian, juga peralatan makan warna-warni dan berbagai ukuran, balok-balok, tumbuhan, sampai multi media (teknologi) canggih sekalipun harus tetap dirancang sesuai usia dan kebutuhan perkembangan anak usia dini. Hal ini dikarenakan guna mengoptimalkan segala potensi yang ada pada diri anak. Sehingga pada gilirannya akan terbentuk pondasi yang kokoh di masa mendatang.

Keywords: ICT, Educational, Early Childhood

\section{PENDAHULUAN}

Kehadiran Information Communication and Technologi (ICT) atau Teknologi Informasi dan Komunikasi (TIK) telah merambah setiap bidang kehidupan manusia, termasuk dalam dunia pendidikan. Peranan ICT dalam dunia pendidikan sangatlah besar, tidak hanya pada jenjang pendidikan tinggi namun juga sampai pada jenjang Pendidikan Anak Usia Dini (PAUD). Ditengah isu antara pro dan kontra penggunaan ICT dalam pendidikan, hal yang bijaksana dapat dilakukan adalah mencari solusi bagaimana memfaatkan kelebihan ICT untuk tujuan mencapai PAUD yang sudah direncanakan.

Pada Amandemen Undang-Undang Dasar 1945 pasal 28 ayat 2, dinyatakan bahwa setiap anak berhak mengembangkan diri melalui pemenuhan kebutuhan dasarnya, berhak mendapatkan pendidikan dan memperoleh manfaat dari ilmu pengetahuan dan teknologi, seni dan budaya, demi meningkatkan kualitas hidupnya dan demi kesejahteraan umat manusia, dalam rangka mengembangkan diri anak usia dini, sekarang banyak kita dapati berbagai layanan pendidikan baik formal maupun non-formal. Apapun bentuk layanan tersebut, seyogyanya memperhatikan prinsip pembelajaran anak usia dini.

Selain memperhatikan prinsip pembelajaran, cakupan materi yang diberikan juga sangat beragam sesuai dengan aspek perkembangan anak. Berbagai media dapat digunakan dari yang terdapat pada tubuh anak sendiri seperti jari tangan dan kaki, pakaian, juga peralatan makan 
warna-warni dan berbagai ukuran, balok-balok, tumbuhan, sampai multi media (IT) canggih sekalipun harus tetap dirancang sesuai usia dan kebutuhan perkembangan anak usia dini.

Perkembangan zaman saat ini telah memasuki suatu era yang merupakan gelombang ketiga dari revolusi perkembangan zaman, yaitu revolusi teknologi elektronika dan informatika. Secara umum perkembangan dalam informasi menurut Miarso menunjukkan ciri-ciri sebagai berikut:

Pertama, meningkatnya daya muat untuk mengumpulkan, menyimpan, memanipulasi, dan menyajikan informasi; Kedua, kecepatan penyajian informasi yang meningkat; Ketiga, miniaturisasi perangkat keras yang disertai dengan ketersediaan yang melimpah; Keempat, keragaman pilihan informasi untuk melayani berbagai macam kebutuhan; Kelima, biaya perolehan informasi, terutama biaya untuk transmisi data yang cepat dalam jarak jauh, yang secara relatif semakin turun; Keenam, kemudahan penggunaan produk teknologi komunikasi dan informasi, baik yang berupa perangkat keras maupun perangkat lunak; Ketujuh, kemampuan distribusi informasi yang semakin cepat dan luas, dan karen itu informasi lebih mudah diperoleh, dengan menembus batas-batas geografis, politis, maupun kedaulatan; Kedelapan, meningkatnya kegunaan informasi dengan keanekaragaman pelayanan yang dapat diberikan hingga memungkinkan pemecahan masalah yang ada secara lebih baik serta dibuatnya prediksi masa depan yang lebih tepat. ${ }^{1}$

Era teknologi informasi sebagaimana telah disebutkan di atas membawa perubahanperubahan serta pengembangan dalam berbagai aspek kehidupan. Tidak terkecuali dalam dunia pendidikan, mulai dari pendidikan anak usia dini hingga perguruan tinggi. Besarnya peran teknologi komunikasi dan informasi membawa peran tersendiri bagi pendidikan baik sebagai pendukung sistem maupun media pembelajaran. Pada artikel ini penulis akan memfokuskan perannya sebagai media pembelajaran yang dikhususkan pada anak usia dini.

\section{PEMBAHASAN}

\section{Hakikat Belajar Anak Usia Dini}

Anak usia dini adalah sosok individu yang sedang menjalani suatu proses perkembangan sangat pesat dan menempati kedudukan sebagai "golden age" (usia emas) yang sangat strategis dalam mengembangkan sumber daya manusia serta sebagai peletak dasar bagi pengembangan pendidikan pada tahap selanjutnya. Mereka selalu aktif, kreatif, dan antusias, serta memiliki rasa ingin tahu sangat tinggi terhadap apa yang dilihat maupun didengar, dan seolah-olah tak pernah berhenti untuk belajar.

Menurut Berk dalam Sujiono mengatakan bahwa, pada masa ini proses pertumbuhan dan perkembangan dalam berbagai aspek sedang mengalami masa yang cepat dalam rentang perkembangan hidup manusia. ${ }^{2}$ Oleh sebab itu, program pembelajaran yang diselenggarakan bagi anak semestinya pembelajaran yang mampu memfasilitasi, mengkondisikan, menumbuhkan aktivitas dan daya cipta serta memberikan dorongan untuk dapat mengoptimalkan segala potensi yang ada pada diri anak. Sehingga pada gilirannya akan terbentuk pondasi yang kokoh di masa mendatang.

Selain itu, pembelajaran pada anak usia dini harus berpedoman pada prinsip belajar seraya bermain atau bermain seraya belajar. Bermain sangat lekat dengan anak-anak, karena bermain merupakan dunia anak-anak. Hampir seluruh waktu jaga di masa anak-anak digunakan untuk bermain. Bermain merupakan tuntutan dan kebutuhan bagi anak usia dini, sehingga kegiatan

\footnotetext{
${ }^{1}$ Yusufhadi Miarso, Menyemai Benih Teknologi Pendidikan. (Jakarta: Pustekom, 2004), h. 5

${ }^{2}$ Yuliani Nurani Sujiono, Konsep Dasar Pendidikan Anak Usia Dini (Jakarta: PT Indeks, 2009), h. 6
} 
pembelajarannya dilakukan dengan berbagai macam permainan dalam suasana yang menyenangkan dan merangsang anak untuk terlibat secara aktif.

Menurut Santrock, bermain merupakan sebuah kegiatan yang menyenangkan yang keterlibatannya untuk kepentingan diri sendiri. ${ }^{3}$ Harlock menjelaskan bermain adalah setiap kegiatan yang dilakukan untuk kesenangan yang ditimbulkannya, tanpa mempertimbangkan hasil akhir. ${ }^{4}$ Bermain dilakukan secara sukarela, tidak ada paksaan atau tekanan dari luar dan bukan pula karena kewajiban.

Belajar merupakan perubahan perilaku atau potensi perilaku yang relatif permanen yang berasal dari pengalaman dan tidak dapat dinisbahkan ke temporary body state (keadaan tubuh temporer) seperti keadaan yang disebabkan oleh sakit, keletihan atau obat-obatan. ${ }^{5}$ Senada yang diutarakan oleh Gagne sebagaimana dikutip oleh Siregar dan Nara menjelaskan, "learning relatively permanent change in behavior that result from past experience or purposeful instruction." Belajar adalah suatu perubahan perilaku yang relatif menetap dihasilkan dari pengalaman masa lalu ataupun dari pembelajaran yang bertujuan atau direncanakan. Perubahan yang dimaksud dalam belajar menyangkut perubahan tingkah laku yang dapat diukur dengan membandingkan tingkah laku yang terjadi sebelum seseorang ditempatkan di dalam suatu situasi belajar dengan tingkah laku setelah mengalami proses belajar.

Menurut Gredler Belajar adalah suatu proses yang dilakukan seseorang untuk memperoleh berbagai kecakapan, keterampilan, dan sikap. ${ }^{7}$ Belajar menghasilkan perubahan dalam pengetahuan, perilaku, pemahaman serta sikap dan perubahan tersebut merupakan kecakapan baru yang terjadi karena adanya usaha secara sadar, sehingga akan berimplikasi pada fungsi kehidupan lainnya.

Berdasarkan uraian dua variabel di atas dapat dipahami bahwa, bermain seraya belajar merupakan kegiatan bermain yang di dalamnya terdapat unsur-unsur belajar. Melalui bermain, tuntutan akan kebutuhan perkembangan dimensi motorik, kognitif, kreatifitas, bahasa, emosi, interaksi sosial, nilai-nilai, dan sikap hidup dapat terpenuhi. Ketika bermain, anak akan berimajinasi dan mengeluarkan ide-ide yang tersimpan dalam dirinya. Anak dapat mengekspresikan pengetahuan yang dia miliki tentang dunia sekitarnya. Melalui kegiatan bermain, anak mempunyai kesempatan lebih banyak untuk bereksplorasi, sehingga pemahaman tentang konsep maupun pengertian dasar suatu pengetahuan dapat dipahami anak dengan lebih mudah.

${ }^{3}$ John w. Santrock, Child Development, Seven Edition, (Chicago: Brown \& Bencmark, 2003), h. 519

4 Elisabeth B. Hurlock, Perkembangan Anak, Edisi Keenam, Jilid 1. Terjemahan Meitasari Tjandrasa dan Muslichah Zarkasi, (Jakarta: Erlangga, 2008), h. 320

${ }^{5}$ B.R. Hergenhahn dan Matthew H. Olson, Theories of Learning, terjemahan Tri Wibowo, (Jakarta: Kencana, 2008), h. 8

${ }^{6}$ Eviline Siregar dan Hartini Nara, Teori Belajar dan Pembelajaran, (Bogor: Ghalia Indonesia, 2010), h. 4

7 Margaret E. Bell-Gredler, Belajar dan Membelajarkan, Terjemahan Munandir (Jakarta: Rajawali, 1991), h. 1 


\section{Pengertian ICT}

ICT (Informations and Communication Technologies) atau di Indonesia dikenal dengan teknologi informasi dan komunikasi merupakan suatu sistem yang terdiri dari sistem informasi dan komunikasi. Masing-masing memiliki pengertian dan ruang lingkup tersendiri.

Teknologi informasi merupakan studi atau penggunaan peralatan elektronika, terutama komputer untuk menyimpan, menganalisis dan mendistribusikan informasi apa saja, termasuk kata-kata, bilangan dan gambar. Lucas dalam munir, menyatakan bahwa teknologi informasi adalah segala bentuk teknologi yang diterapkan untuk memproses dan mengirim informasi dalam bentuk elektronik, micro komputer, komputer mainframe, pembaca barcode, perangkat lunak memproses transaksi, perangkat lembar kerja dan peralatan komunikasi dan jaringan merupakan contoh teknologi informasi. ${ }^{8}$ Informasi yang disampaikan berupa pesan-pesan elektronik. Sedangkan teknologi komunikasi merupakan perangkat-perangkat teknologi yang terdiri dari hardware, software, proses dan sistem, yang digunakan untuk membantu proses komunikasi, yang bertujuan agar komunikasi berhasil.

Teknologi Informasi menekankan pada pelaksanaan dan pemerosesan data seperti menangkap, mentransmisikan, menyimpan, mengambil, memanipulasi atau menampilkan data dengan menggunakan perangkat-perangkat teknologi elektronik terutama komputer. Sedangkan teknologi komunikasi menekankan pada penggunaan perangkat teknologi elektronika dan lebih menekankan pada aspek ketercapaian tujuan dalam proses komunikasi, sehingga data dan informasi yang diolah dengan teknologi informasi harus memenuhi kriteria komunikasi yang efektif.

Secara singkat dapat dipahami bahwa teknologi informasi lebih pada sistem pengolahan informasi sedangkan teknologi komunikasi berfungsi untuk pengiriman informasi. Teori lain merumuskan definisi dari teknologi informasi dan komunikasi sebagai sesuatu yang mengizinkan kita memperoleh informasi untuk berkomunikasi dengan setiap orang atau untuk memiliki sebuah pengaruh pada lingkungan yang sedang menggunakan peralatan elektronik dan digital.

Sejatinya TIK memiliki potensi yang besar untuk dapat dimanfaatkan sebagai media dalam pembelajaran dari anak usia dini sampai perguruan tinggi. Rencana cetak biru TIK Depdiknas, paling tidak menyebutkan tujuh fungsi TIK dalam pendidikan, yaitu sebagai sumber belajar, alat bantu belajar, fasilitas pembelajaran, standard kompetensi, sistem administrasi, pendukung keputusan, dan sebagai infrastruktur.

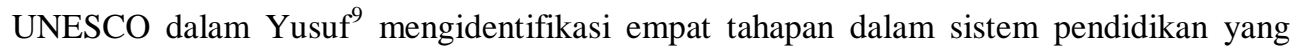
mengadopsi TIK, yaitu :

a. Tahap emerging; yaitu perguruan tinggi/sekolah berada pada tahap awal. Pendidik dan tenaga kependidikan mulai menyadari, memilih/membeli, atau menerima donasi untuk pengadaan sarana dan prasarana (supporting work performance)

b. Tahap applying; yaitu perguruan tinggi/sekolah memiliki pemahaman baru akan kontribusi TIK. Pendidik dan tenaga kependidikanu menggunakan TIK dalam manajemen sekolah dan kurikulum (enhancing traditional teaching)

c. Tahap infusing; yaitu melibatkan kurikulum dengan mengintegrasikan TIK. Perguruan tinggi/sekolah mengembangkan teknologi berbasis komputer dalam lab, kelas, dan

\footnotetext{
${ }^{8}$ Munir, Kurikulum Berbasis Teknologi Informasi dan Komunikasi, (Bandung: Alfabeta, 2008), h. 18

9 Adie E. Yusuf, https://teknologikinerja.wordpress.com/2008/05/02/hello-world/, Diakses Pada Tanggal 15 September 2017.
} 
administrasi. Pendidik dan tenaga kependidikan mengekplorasi melalui pemahaman baru, dimana TIK mengubah produktivitas professional (facilitating learning).

d. Tahap Transforming; yaitu perguruan tinggi/sekolah telah memanfatkan TIK dalam seluruh organisasi. Pendidik dan tenaga kependidikan menciptakan lingkungan belajar yang integratif dan kreatif (creating innovative learning environment) melalui TIK.

\section{Pemanfaatan ICT Dalam Pembelajaran Anak Usia dini}

ICT dalam pendidikan memiliki peran yang sangat penting. Seperti yang telah dijelaskan sebelumnya, bahwa di samping sebagai pendukung kinerja sistem pendidikan, ICT juga bermanfaat sebagai media dalam proses pembelajaran. Media pembelajaran berbasis ICT bagi anak usia dini telah membawa kita pada cara yang baru dalam mengembangkan teknologi pembelajaran.

Pembelajaran ICT pada anak usia dini ini memiliki banyak persepsi, diataranya, pemanfaatan ICT sebagai media belajar atau mengajarkan ICT pada mereka. Namun demikian, keduanya terkadang saling berhubungan walaupun banyak juga perbedaan dalam segi orientasi dan pemanfaatan.

Pemanfaatan ICT sebagai media pembelajaran merupakan hal yang baru dalam dunia pendidikan. Hal tersebut tentu diiringi oleh perkembangan zaman saat ini. Dikeluarkannya komputer mini (notebook) oleh pabrikan komputer di dunia yang niat awalnya didistribusikan untuk konsumsi pelajar, merupakan salah satu jalan bagi dunia pendidikan dalam memanfaatkan ICT tersebut dalam proses pembelajaran. Clark dalam Win mengklasifikasinya media dalam pembelajaran menjadi lima perspektif, yaitu:

a. Media sebagai teknologi dan mesin

b. Media sebagai tutor

c. Media sebagai alat sosialisasi

d. Media sebagai motivator dalam belajar

e. Media sebagai alat mental untuk berpikir dan memecahkan masalah ${ }^{10}$

Proses belajar mengajar pada hakikatnya adalah proses komunikasi, yaitu proses penyampaian pesan dari sumber pesan melalui saluran atau media tertentu kepada penerima pesan. Pesan, sumber pesan, saluran/media dan penerima pesan adalah komponen-komponen proses komunikasi. Pesan yang dikomunikasikan adalah sebuah informasi.

Teknologi bagaikan dua sisi mata uang yang berbeda, yang memiliki sisi positif dan negatif. Sehingga implementasinya pun akan berbeda pada setiap usia perkembangan anak, Ada banyak cara mengenalkan teknologi pada anak usia dini, yaitu:

a. Usia 0-2 tahun: Pada perkembangan anak usia ini, anak mulai belajar mendengar dan mengenal sekitarnya, dari rangsangan-rangsangan yang ditimbulkan melalui gerakan, serta suara. Kemudian anak mulai menirukan ketika mereka mulai belajar berbicara. Pemberian IT

\footnotetext{
${ }^{10}$ Win W. D, Comunication, Media, and Instrumentation in International Encyclopedia of Educational Technology, (Pergamon: UK, 1996), h. 26
} 
pada usia anak demikian, dapat melalui multimedia dengan cara diputarkan lagu-lagu rohani atau lagu anak. Mengenalkan warna juga dapat melalui multimedia dengan memutarkan film-film kartun anak, yang sifatnya mendidik. Film-film kartun saat ini memiliki unsur warna yang beragam, sehingga anak dapat mengenalnya walau tidak sekaligus, tetapi warnawarna yang dominan. Hal ini pun dapat membantu pembentukan karakter anak.

b. Usia 3-4 tahun: Pada usia ini, anak mulai menggunakan kalimat yang hampir lengkap, hal ini dapat dilihat dari cara mereka menanyakan sesuatu hal. Menurut Piaget, cara anak mengajukan pertanyaan menunjukkan perkembangan kognitif seorang anak. Pada anak yang berasal dari latar belakang orang tua otoriter, anak kurang belajar berbicara, ketimbang dalam keluarga yang demokratis, dimana anak bukan saja belajar "mendengar" tetapi juga “didengar”. Oleh karenannya penting diberikan IT melalui multimedia, dengan cara seperti pada usia anak 0-2 tahun, tetapi cara pembelajarannya sedikit meningkat disesuaikan dengan usia anak yang telah dapat menerima rangsangan lebih banyak. Misalnya mulai diajarkan melafalkan ayat-ayat suci Al Qur'an, atau dikenalkan cerita-cerita Kitab Suci melalui filmfilm, tentu saja perlu pendampingan orang tua sehingga dapat terlihat sejauh mana anak mampu untuk belajar. Semakin banyak kesempatan anak belajar untuk berbicara, dapat membantu anak menumbuhkan rasa percaya dirinya sehingga pada usia sekolah mereka dapat mengenalkan dan mengungkapkan dirinya secara lisan.

c. Usia 5-6 tahun: Pada usia ini, pengenalan dunia IT sudah lebih meningkat. Pengenalan dapat berupa pengenalan perangkat keras komputer (hardware) yang bisa dilihat dan dipegang langsung oleh anak, misalnya: CPU, Monitor, Mouse, Keyboard dan Printer. Pengenalan perangkat keras ini juga dilengkapi dengan penjelasan fungsi dari masing-masing alat dengan cara langsung dipraktikkan (learning by doing).

d. Usia 7-8 tahun: pada usia ini, pengenalan dunia IT sudah masuk pada tingkat program interaktif, dimana anak sudah bisa berinteraksi dengan program aplikasi pembelajaran.

Adapun fungsi utama TIK dalam Pembelajaran Anak Usia Dini (PAUD) ${ }^{11}$, yakni:

1. Teknologi berfungsi sebagai alat (tools), mengandung pengertian dalam hal ini perangkat teknologi digunakan sebagai alat bantu dalam proses pembelajara, misalnya sebagai alat untuk mengolah kata, mengolah angka, membuat grafik, dan lain-lain.

2. Teknologi informasi berfungsi sebagai ilmu pengetahuan (science), mengandung pengertian bahwa teknologi adalah bagian dari disiplin ilmu yang harus dikuasai peserta didik, misalnya teknologi komputer menjadi jurusan di sekolah atau adanya mata pelajaran TIK di sekolah sehingga menuntut peserta didik untuk menguasai kompetensi tertentu dalam TIK.

11 https://www.paud.id/2015/09/Prinsip dan Manfaat TIK Dalam Pembelajaran PAUD.html. Diakses tanggal 10 September 2017. 
3. Teknologi sebagai bahan dan alat bantu untuk proses pembelajaran (literacy), mengandung makna bahwa teknologi berfungsi sebagai bahan pembelajaran sekaligus sebagai alat bantu untuk menguasai kompetensi tertentu melalui bantuan komputer.

Jika mengacu pada tiga fungsi TIK dalam pembelajaran, maka khusus untuk pembelajaran anak usia dini, pendidik dapat menentukan salah satu atau setidaknya dua fungsi, yaitu teknologi sebagai alat (tools) dan/atau sekaligus sebagai bahan untuk menstimulasi dalam pencapaian perkembangan tertentu.

Pemanfaatan TIK dalam PAUD yang layak bagi anak tentu harus mempertimbangkan prinsip dalam penyediaan sarana dan prasarana pembelajaran bagi anak usia dini, sekalipun dalam praktiknya ddapat dikendalikan oleh atau dibawah pengawasan pendidik. Selain itu perangkat TIK yang digunakanpun disesuaikan dengan memperhatikan perkembangan anak. Efektif tidaknya pemanfaatan TIK bagi proses tumbuh kembang anak usia dini mutlak menjadi pertimbangan para guru sebelum menentukan untuk memilih jenis perangkat yang tepat.

Oleh sebab itu, pemanfaatan TIK dalam proses pembelajaran perlu dirancang, direncanakan, dilaksanakan dan selalu dievaluasi dari waktu ke waktu agar pemanfaatan TIK dalam pembelajaran PAUD dapat benar-benar maksimal dari segi dukungannya pada pelaksanaan fungsi dan tercapainya tujuan dalam rangka menyiapkan generasi bangsa yang cerdas dan ceria, perlu mengoptimalkan kemanfaatannya dan menimalkan dampak negatifnya.

\section{Dampak ICT Terhadap Perkembangan Anak}

Perkembangan teknologi dan pembangunan yang semakin pesat dari tahun ke tahun membuat para orang tua juga merasa harus menyesuaikan perkembangan anaknya agar tidak zaman. Sudah bukan hal yang baru lagi jika melihat anak sekolah dasar menenteng gadget mahal untuk menghabiskan waktu nya. Aktifitas di luar rumah pun semakin berkurang, sehingga anak akan mengalami ketergantungan terhadap teknologi dan kesadaran terhadap lingkungan semakin hilang.

Perkembangan teknologi memang tidak bisa di cegah atau pun di hindari. Peralihan zaman sudah sewajar nya mengalami perkembangan, tetapi memberi keleluasaan pada anak akan kemudahan teknologi juga bisa berdampak buruk bagi pertumbuhan mereka. Masa kanak kanak adalah masa pencarian jati diri dan penyesuaian terhadap lingkungan.

Banyak para orang tua yang merasa bangga apabila anak nya unggul dan piawai dalam mengoperasikan teknologi. Ini jelas pemahaman yang salah, orang tua berperan penting untuk masa depan mereka. Anak ibaratkan kertas putih yang kosong dan orang tua adalah pensil warna. Oleh sebab itu dibutuhkan kehati-hatian dalam mengolah kertas kosong tersebut agar tidak di kotori oleh gambar serta pemahaman yang salah. 
Adapun dampak-dampak teknologi bagi perkembangan anak ${ }^{12}$, adalah sebagai berikut:

1. Anti sosial

Kehadiran teknologi membuat mereka menjauhi pergaulan secara langsung dan hal ini akan memberi peluang terhadap gejala gangguan kepribadian "Anti sosial" untuk berkembang.

2. Kurang empati

Teknologi membuat anak jarang mengolah perasaan nya terhadap kesulitan orang lain. Hal ini tentu akan melahirkan sebuah pribadi yang angkuh dan sombong

3. Antipati lingkungan/alam

Kurang berinteraksi dengan alam membuat anak tidak sadar lingkungan. Padahal mereka adalah generasi yang harus melestarikan alam dan lingkungan untuk kelangsungan hidup manusia, apalagi eksploitasi alam semakin merajalela.

4. Perilaku konsumtif

Teknologi yang berkembang pesat dengan tambahan fitur-fitur yang semakin canggih, membuat anak selalu menuntut pembaruan gadget dan tidak pernah puas akan gadget yang di milikinya.

5. Krisis akhlak \& moral

Semakin Canggih nya teknologi membuat anak bisa mengakses apa saja termasuk pornografi dan berita kriminal yang akan menjadi acuan tindakan kriminal sebagai solusi pemecahan masalah. Ini di sebabkan proses 'meniru' pada anak sangat tinggi.

Penelitian lain tentang dampak ICT dalam hal ini pengaruh komputer terhadap perkembangan intelegensi telah banyak dilakukan oleh para pakar. Penggunaan komputer secara cerdas akan secara timbal balik mempengaruhi kecerdasan. Komputer mampu memenuhi rasa ingin tahu manusia.

Di samping itu, kecepatan, kecermatan, keterkinian informasi dapat diperoleh melalui sistem jaringan komputer. Dengan demikian terjadi pengayaan fungsi otak, yang pada gilirannyameningkatkan produksi sel neuro glial, yaitu sel khusus yang mengelilingi sel neuron, sehingga menambah aktivitas sel neuron.

Mengingat bahwa "pabrik otak" itu diwujudkan sebagai hasil interaksi antar cetak biru genetis dan pengaruh lingkungan. Menurut Clark dalam Jamaris menjelaskan bahwa, otak berfungsi hanya $5 \%$, sehingga sebagian besar informasi tidak digunakan. ${ }^{13}$ Pada gilirannya kerja fungsi intelegensi yang bersumber dari otak secara timbal balik dipengaruhi dan mempengaruhi

\footnotetext{
${ }^{12}$ Widya Indah, https://www.kompasiana.com/iindalosta/dampak-teknologi-bagi-perkembangananak. Diakses Tanggal 15 agustus 2017.

${ }^{13}$ Martini Jamaris, Perkembangan dan Pengembangan Anak Usia Taman Kanak-Kanak, Pedoman Bagi Orang Tua dan Guru, (Jakarta: PT Grasindo, 2008), h. 57
} 
pembelajaran, akan dipersoalkan sampai dimana pengaruhnya dalam peningkatan kecerdasan emosi pada anak.

Berikutnya, penelitian berkenaan dengan pengaruh komputer terhadap perkembangan intelegensi diperoleh pengaruh yang positif dari keduanya. Hal tersebut karena "kerjasama' antara komputer-otak dan intelegensi yang satu dengan lainnya mendorong manusia untuk makin tahu memenuhi rasa ingin tahunya, yang merupakan sifat khas manusia.

Komputer dengan jaringannya dalam kehidupan sekarang tidak terpisahkan dari berbagai kepentingan untuk memperoleh informasi yang cepat, cermat, lengkap, dan aktual. Dengan demikian akan membawa kita secara amat signifikan dalam menyelesaikan berbagai persoalan berkat informasi yang dihadapi. Dengan demikian tidak salah jika penggunaan komputer dengan program yang sesuai dengan umur anak-anak dapat dilakukan.

Menurut Goleman dalam bukunya Emotional Intelligence menjelaskan bahwa dalam kehidupan mental seorang anak ada dua aspek, yaitu rasio dan emosi, yang masing-masing tidak pernah berdiri secara terpisah, melainkan dihayati secara bersamaan, bercirikan pemahaman dan kesadaran yang berasal dari otak seseorang; sedangkan emosi yang bersifat kuat dan impulsif bersumber dari hati sanubari atau bahkan juga dari hati nurani seseorang. ${ }^{14}$ Emosi merupakan suatu kondisi tergerak untuk berbuat, dengan demikian, emosi memiliki beberapa komponen yaitu gerak untuk bertindak, menghayati perasaan yang bersifat subjektif, dan kesadaran tentang emosi itu atau dengan kata lain, memiliki unsur subjektif, perilaku, fisiologis.

Selanjutnya Leventhal dalam Goleman, mengalihkan paradigma tersebut dalam menjelaskan rasio dan emosi yang terkait dengan information processing sebagai berikut: ada empat sistem yang terintegrasi dalam model emosi ini, yaitu 1) interpretasi sistem dalam mewujudkan penghayatan emosi, 2) sistem ekspresif, yang merupakan umpan balik yang menandai kualitas subjektif emosi, 3) sistem tindak instrumental dan 4) sistem reaksi jasmaniah. ${ }^{15}$

Teori ini didasarkan atas lima asumsi, yaitu 1) kajian emosi harus beranjak dari laporan verbal pengalaman subjektif, 2) kondisi emosional adalah suatu bentuk kebermaknaan, sehingga kalau kognisi adalah makna, emosi membentuk kognisi, 3) ada berbagai bentuk kognisi abstrak, 4) sistem kebermaknaan berkembang dan berubah, 5) perlu sistem makna khusus.

Memang dampak buruk dari penggunaan teknologi tidak bisa di rasakan sekarang. Namun seiring dengan perkembangan usia, mereka mulai membentuk pola tingkah laku negatif yang jika ditelusuri bersumber dari masalah ini. Untuk itu, diharapkan perhatian para guru dan orang tua ke arah ini untuk lebih bijaksana dalam menentukan batasan-batasan apa yang boleh, apa yang tidak

\footnotetext{
${ }^{14}$ Daniel Goleman, Emotional Intellegence, Terjemahan Hariono S. Iman, (Jakarta: PT Gramedia, 1996), h. 57

${ }^{15}$ Ibid, h. 59
} 
boleh dan diperbolehkan dengan syarat. Masa depan generasi penerus bangsa ini bergantung pada para orang tua yang cerdas dan bijaksana serta peduli masa depan anak bangsa.

\section{KESIMPULAN}

Berdasarkan uraian di atas dapat ditarik kesimpulan bahwa, saat ini kita tidak dapat melepaskan diri dari perkembangan teknologi informasi dan komunikasi (TIK), karena telah menjadi bagian dari kehidupan dan kebutuhan. Pola kehidupan tersebut berimbas pada pengembangan pendidikan yang memanfaatkan TIK khususnya sebagai media pembelajaran. Sebagai usaha mengembangakan kemampuan individu dalam penggunaan TIK secara praktis maka perlu dikenalkan sejak usia dini.

Pengembangan kemampuan anak usia dini dalam TIK harus tetap dilakukan sesuai konsep pembelajaran anak usia dini yakni belajar seraya bermain dan bermain seraya belajar. Materi maupun bahan ajar yang diberikan juga harus bervariasi dan tidak monoton dengan berbagai karakteristik TIK sebagai media pembelajaran sehingga imajinasi dari anak tersebut dapat berkembang secara optimal seiring dengan pertumbuhan usia mereka. Sehingga semakin meningkatkan kemampuan intelektual dan emosional mereka.

\section{REFERENSI}

Miarso, Yusufhadi, 2004. Menyemai Benih Teknologi Pendidikan. Pustekom: Jakarta.

Jamaris, Martini, 2008. Perkembangan dan Pengembangan Anak Usia Taman Kanak-Kanak, Pedoman Bagi Orang Tua dan Guru. Jakarta: PT Grasindo.

Goleman, Daniel, 1996. Emotional Intellegence, Terjemahan Hariono S. Iman, Jakarta: PT Gramedia.

Munir, 2008. Kurikulum Berbasis Teknologi Informasi dan Komunikasi. Alfabeta: Bandung

Win W. D, 1996. Comunication, Media, and Instrumentation in International Encyclopedia of Educational Technology. Pergamon: UK.

Hurlock, Elisabeth B, 2008. Perkembangan Anak, Edisi Keenam, Jilid 1. Terjemahan Meitasari Tjandrasa dan Muslichah Zarkasi. Jakarta: Erlangga.

Hergenhahn, B. R dan Matthew H. Olson, 2008. Theories of Learning, terjemahan Tri Wibowo. Jakarta: Kencana.

Siregar, Eviline dan Hartini Nara, 2010. Teori Belajar dan Pembelajaran. Bogor: Ghalia Indonesia. Bell-Gredler, Margaret E, 1991. Belajar dan Membelajarkan, Terjemahan Munandir. Jakarta: Rajawali.

Nurani Sujiono, Yuliani, 2009. Konsep Dasar Pendidikan Anak Usia Dini. Jakarta: PT Indeks.

Santrock, John W, 2003. Child Development, Seven Edition. Chicago: Brown \& Bencmark. https://www.paud.id/2015/09/Prinsip dan Manfaat TIK Dalam Pembelajaran PAUD.html, Diakses tanggal 10 September 2017.

Yusuf, Adie E. https://teknologikinerja.wordpress.com/2008/05/02/hello-world/, Diakses Pada Tanggal 15 September 2017. 
Widya Indah, https://www.kompasiana.com/iindalosta/dampak-teknologi-bagi-perkembangananak. Diakses Tanggal 15 agustus 2017. 